ing an enzyme and therefore such a thing as a pure enzyme is now unknown. For this reason the chemical analyses of dried "enzyme preparations" signify little, because it is impossible to know what portion of the preparation is enzyme and what is impurity. Pending the discovery of some method for crystallizing enzymes this branch of their study is practically at a standstill. On the other hand, the study of the mode of action of enzymes and the influence of temperature, acids, etc., upon their catalyzing power is advancing rapidly and it is with this subject that Professor Euler's treatise deals. To quote from the preface, he "has attempted to review the more important facts of enzymology from a general standpoint and to fit them, as far as is possible, into their proper places in the fabric of general and physical chemistry." This book is the first in which an attempt has been made to describe this branch of science from the standpoint of theoretical chemistry and special credit is due Professor Euler for his excellent treatment of the subject. The following chapter titles may serve to give an idea of the contents of the book: Special chemistry of the enzymes, their physical properties, their activators and poisons, the chemical dynamics of enzyme reactions, the influence of temperature and radiation on enzymic reactions, the chemical statics of enzyme reactions, enzymic syntheses and the specificity of enzyme action. The work of translation by Mr. Pope has been very carefully done. The publishers are also to be commended for the quality of the printing and binding.

\section{S. Hudson}

SPECIAL ARTICLES

MITOCHONDRIA IN ASCARIS SEX-CELLS

DuRING the course of preparation of a thesis for the Doctor's degree at the University of Pennsylvania, entitled "The Spermatogenesis of Ascaris megalocephala with special reference to the two Cytoplasmic Inclusions, the Refractive Body and the 'Mitochondria'; their Origin, Nature and Rôle in Fertilization," the following observations were made:

The refractive body arises, as Marcus
(1906), Mayer (1908) and Romieu (1911) point out, by the fusion of the refringent vesicles while still in the vas-probably just before copulation occurs. The refringent vesicles arise from minute granules scattered here and there throughout the cytoplasm in the early growth period of the spermatocyte. These granules stain blue after the material is fixed in Benda's modification of Flemming's strong solution and stained in Benda's "Krystal Violet." This reaction is characteristic of true mitochondria. Granules staining exactly like these are found constantly in the nucleus of the spermatogonium, and these actually pass through the nuclear membrane into the cytoplasm of the spermatocyte. This blue staining material, or true mitochondria, is apparently derived directly from the chromatin because in several cases chromosomes in the spermatogonial nuclei were cut, showing the red-brown interior (the typical reaction to Benda's stain for chromatin) covered by a blue layer. Thus the refractive body is ultimately derived from the chromatin of the spermatogonium, and it is formed by true mitochondria; these are not only nuclear in origin, they are derivatives of the karyosome. They should, therefore, be called karyochondria to distinguish them clearly from the plastochondria (Meves) which are derived from the plasmosome of the spermatogonial nucleus.

The refractive body has but one functionnamely, to feed the spermatozoon on its long and exhausting journey (by pseudopodial creeping) to the "entrance region" at the proximal end of the uterus. This is proven by the fact that many eggs are entered there by spermatozoa which have lost every trace of the refractive body; and further, by the fact that the decrease in size of this body takes place equally from all sides, showing that it is the surrounding layer of cytoplasm, and not the uterine epithelial cells, as all other authors maintain, which is the agent of its absorption. Not only is its axial symmetry maintained during the stages of degeneration while crowded between the epithelial cells, but also when lying amongst eggs far out in the 
lumen of the uterus. So it is fed upon only by the sperm itself.

The nematodes should, therefore, be placed in Faure-Fremiet's (1910) fourth class of mitochondria-bearing sex-cells, in which these granules produce yolk.

Marcus, Mayer, Romien and Faure-Fremiet use the term mitochondria to describe minute plastin granules found in the nucleus of the spermatogonium and in both nucleus and cytoplasm of the spermatocyte. They are easily seen in the "perinuclear zone" of the spermatid and in the "crown" of the spermatozoon. But nowhere do these granules take Benda's Krystal violet stain or transform into any cell structure. Hence they have no relationship with true mitochondria. Meves recognizes their nature and origin and calls them plastochondria. Van Beneden called them "protoplasmic corpuscles"; Altmann, "microsomes"; Boveri, "archoplasm." But none of these observers attributed any importance to them as bearers of hereditary characters. Meves (1910), however, finds (like the brothers Roja, 1891) that these granules fuse with similar ones in the egg after fertilization occurs, and he believes, with only this observation as a basis for it, that these plastochondria are the bearers of paternal structural characteristics. I have carefully studied the origin and behavior of these granules throughout the spermatogenesis and find that they everywhere behave, like the plasmosome itself, as if they were waste products of the metabolic processes of the chromatin. Many of them are actually thrown off by the spermatid with the cytoplasmic lobe, not only in Ascaris, but in many other forms. They always take plasma stains, yellow after Benda, and red after Ehrlich-Bionde, both reactions characteristic of secretions; they are pulled about in the cell by the force of the centrosomes to form aster rays and spindle fibers of the cleavage figure; they never divide, nor grow except by fusion on actual contact; in short, they behave everywhere as inert formed products only.

I believe that the observed facts of artificial parthenogenesis, hybridization and fertilization of enucleated eggs, all argue against Meves' interpretation of the rôle of the plastochondria; while these facts and the observations of Baltzer, Tennant and others show clearly that it is the retention or elimination of chromatin (or the karyochondria) that determines the inheritance of paternal characters, segregation and dominance.

EDWARD E. WILDMaN

\section{THE AMERICAN ASSOCIATION FOR THE ADVANCEMENT OF SCIENCE}

\section{SECTION E-GEOLOGY AND GEOGRAPHY}

The sixty-fourth meeting of Section E, Geology and Geography, of the American Association for the Advancement of Science, was held in the geological lecture room, main building, Case School of Applied Science, December 30, 1912, to January 2, 1913. Vice-president James E. Todd presided. The address of the retiring Vicepresident, Professor B. Shimek was given on the subject, "The Significance of the Pleistocene Mollusks." Much interest was taken in the papers, which are here given with abstracts:

Esker Terraces in Ohio: G. FREDERICK WRIGHT.

The Wisconsin Drift-plain in the Region about Sioux Falls, S. D. (illustrated): J. ERNEST Carman.

The region considered lies to the south of Sioux Falls along the line between Lineoln and Minnehaha counties, South Dakota. Professor Todd and others have interpreted it as belonging to the Wisconsin drift-plain, being an eastward projection of the James River lobe to the Big Sioux Valley. Professor Shimek has recently decided that the region is a Kansan drift-plain and not Wisconsin. The present paper describes the characteristics of this plain north and west of Shindlar and compares it with the typical Kansan region to the north and east. The evidence, ehiefly physiographic, indicates that the region is a Wisconsin drift-plain. The conclusions of the paper support, in the main, the earlier interpretation of Professor Todd.

The Pleistocene Succession in Wisconsin: SAMUEL WEIDMAN.

A brief statement is given concerning present knowledge of the drift and associated surface deposits in Wisconsin, with a map showing distribution of the formations. There appear to be 